$1-1-1996$

\title{
The ants (Hymenoptera: Formicidae) of Polynesia revisited: Species numbers and the importance of sampling intensity
}

Lloyd W. Morrison

Follow this and additional works at: https://bearworks.missouristate.edu/articles-cnas

\section{Recommended Citation}

Morrison, Lloyd W. "The ants (Hymenoptera: Formicidae) of Polynesia revisited: species numbers and the importance of sampling intensity." Ecography 19, no. 1 (1996): 73-84.

This article or document was made available through BearWorks, the institutional repository of Missouri State University. The work contained in it may be protected by copyright and require permission of the copyright holder for reuse or redistribution.

For more information, please contact BearWorks@library.missouristate.edu. 


\title{
The ants (Hymenoptera: Formicidae) of Polynesia revisited: species numbers and the importance of sampling intensity
}

\author{
Lloyd W. Morrison
}

\begin{abstract}
Morrison, L. W. 1996. The ants (Hymenoptera: Formicidae) of polynesia revisited: species numbers and the importance of sampling intensity. - Ecography 19: 73-84.

The ant faunas of three remote Polynesian islands were censused using hand collecting techniques. Known ant species richnesses were increased by factors of 2.3 , 3.7 , and 4.3 , and total species richnesses were estimated with a first-order jackknife estimator. The large increase in species numbers is apparently due to inadequate earlier censuses (which missed localized and cryptic species) rather than recent immigrations. Tests of species associations revealed more positive than negative interactions among species, on both a pairwise and community-wide basis. There is no evidence that ant species on these islands exclude each other from islands or from communities within islands, with the exception of three very aggressive species.

A multiple regression analysis of known ant species richness against sampling effort and area for Polynesian islands which have been differentially censused for ants by various collectors revealed sampling effort was highly significant, while area was not significant, in explaining variation in known ant species numbers. On Pacific islands that have been surveyed relatively thoroughly for ants, multiple regression analyses of known ant species richness on area and distance showed that area was always highly significant, but distance was only marginally significant (depending on the regression model used). Thus remote Polynesian islands appear neither to be as depauperate as previously thought in numbers of ant species present, nor possess an unusual potential for evolutionary increase in species numbers.
\end{abstract}

L.W. Morrison, Sect. of Evolution and Ecology, Div. of Biol. Sciences and Center for Population Biology, Univ. of California, Davis, CA 95616, USA. (Present address: Brackenridge Field Lab. and Dept of Zoology, University of Texas, Austin, TX 78712, USA).

In 1967, Wilson and Taylor (1967a, b) published two papers which summarized all that was known at the time about the ants of Polynesia. Wilson and Taylor (1967a) reviewed all previous records and collections of ants from the area, producing a taxonomic key and describing distribution patterns for all the known species. They found that most islands contained a large proportion of cosmotropical "tramp" species which had been introduced by foreign commerce, and that islands in eastern Polynesia (east of Rotuma, Samoa and Tonga) had no native species at all. This monograph represented an unsurpassed achievement for ant taxonomy in this region, and is still the standard reference work today.
Wilson and Taylor (1967b) made evolutionary predictions for the Polynesian ant fauna. Based on the relatively low species numbers (compared to other. less remote Pacific islands), the presence of primarily tramp species, and the apparent importance of interspecific competition in limiting species distributions, Wilson and Taylor hypothesized that species numbers were at a "quasi-equilibrium" and would not increase in the short term by continued immigration, but only in evolutionary time through "local adaptation". They estimated the potential for evolutionary increase to be ca 1.5 to 2 times the known species numbers.

Accepted 9 August 1995

Copyright (C) ECOGRAPHY 1996

ISSN 0906-7590

Printed in Ireland - all rights reserved 
Very few studies of Polynesian ant distributions have been reported in the intervening 26 years (Huddleston and Fluker 1968, Perrault 1988, Reimer et al. 1990), and the evolutionary theories of Wilson and Taylor (1967b) remain accepted (Holldobler and Wilson 1990), yet untested. However, the results of a study I report here, along with consideration of a few other records scattered through the literature, provide more detailed evidence of ant distributions on a number of Polynesian islands, and allow a re-evaluation of these theories.

This paper specifically addresses the following questions: Are remote Polynesian islands depauperate today in numbers of ant species (on an areal basis) relative to other, less remote Pacific islands? How do the results of recent surveys for ants on Polynesian islands compare to earlier surveys, and how can any discrepancies be accounted for? What role does interspecific competition play in shaping the distribution of ants within and among these islands? And finally, does there exist a large potential for evolutionary increase in the Polynesian ant fauna?

\section{Study area}

I conducted the field work for this study on the islands of Moorea, Huahine, and Bora Bora in the Society Islands, French Polynesia. All three islands are volcanic in origin and topographically very diverse, with high, jagged mountain peaks surrounded by a narrow coastal plain. Moorea $\left(17^{\circ} 30^{\prime} \mathrm{S}, 149^{\circ} 50^{\prime} \mathrm{W}\right)$ is both the largest $\left(136 \mathrm{~km}^{2}\right)$ and highest $(1207 \mathrm{~m})$ of the three. Huahine $\left(16^{\circ} 45^{\prime} \mathrm{S}, 151^{\circ} 00^{\prime} \mathrm{W}\right)$ is smaller in size $\left(73 \mathrm{~km}^{2}\right)$ and not as high $(710 \mathrm{~m})$; Bora Bora $\left(16^{\circ} 30^{\prime} \mathrm{S}, 151^{\circ} 45^{\prime} \mathrm{W}\right)$ is the smallest $\left(30 \mathrm{~km}^{2}\right)$, but is relatively high for its size $(727$ m) (Gabrie and Salvat 1985).

The climate of French Polynesia is a tropical one, with a warm, rainy season from October to April, and a cooler, drier season from June to September. On Moorea, where the majority of work for this study was done, temperatures range from 25 to $30^{\circ} \mathrm{C}$, with a greater average daily variation $\left(6^{\circ} \mathrm{C}\right)$ than average annual variation $\left(3^{\circ} \mathrm{C}\right)$. Relative humidity ranges from 80 to $90 \%$ in the wet season, and from 70 to $80 \%$ in the dry season. Average annual precipitation exceeds 4000 $\mathrm{mm}$ in the higher altitudes but is $<2000 \mathrm{~mm}$ along the coast (Galzin and Pointier 1985). The climates of the neighboring islands of Bora Bora and Huahine are similar.

\section{Methods}

I collected ants on Moorea from 21 January to 31 March 1991, and 16-31 March 1992. I collected ants on Bora Bora 3-8 April 1992, and on Huahine 9-15
April 1992. Because many methods of ant collecting exist, and the efficacy of each depends on the habitat in question (Romero and Jaffe 1989), I initially examined four different methods of determining the ant species composition at a given site: tuna baiting (on the ground), pitfall trapping, leaf-litter sifting and hand collecting. (No exclusively arboreal ants exist on these islands; even species which forage and/or nest in the trees also forage on the ground to some extent).

Tuna baits placed on the ground (left out over a 1-2 $h$ period) tended to underestimate the true ant species richness because aggressive species monopolized the baits. Pitfall traps captured most of the species known to be present at a site, but this method required that all sites would have to be visited twice, which was not practical for the more remote areas. Hand collecting and leaf litter sifting (see Ward (1987) for a description of the litter sifting technique) both worked well in determining species richness at a site; there was no significant difference in numbers of species found by the two methods at nine sites where both techniques were employed ( $\mathrm{p}=0.58$; paired, two-tailed t-test).

However, hand collecting was by far the least time consuming of all the above methods, and it revealed some rather common species which were not detected using the other methods (e.g. the subterranean species Pachycondyla cf. testacea Motschulsky). Furthermore, no species were found by any of the other methods which were not also detected by hand collecting. Thus, hand collecting was chosen as the most efficient technique to sample the ant species inhabiting these islands.

Specifically, hand collecting involved the following: I collected foraging workers crawling on the ground and on the vegetation. I also turned over rocks, leaves, and logs; broke open woody vegetation; and dug through the leaf litter and soil searching for ants. Collections were made from nests when they were found. I collected at specific predetermined sites, which were ca 300 $\mathrm{m}^{2}$ in area. I spent from 60 to $90 \mathrm{~min}$ at each site, depending on whether new species continued to be found. On each island, collection sites were chosen to be representative of all the major habitat types, and spread out over the island as uniformly as the terrain permitted. Topographic maps and an altimeter were used to determine the locations and elevations of each site. I collected from 153 sites on Moorea, 29 on Huahine, and 26 on Bora Bora.

I characterized each site that I sampled on the main islands as "disturbed" or "undisturbed", primarily on the basis of the vegetation. Disturbed sites included roadsides, fields, gardens, lawns, plantations and other areas which exhibited recent alteration of the natural habitat by human activity. Undisturbed sites were those which had no recent signs of human alteration. The relative disturbance of an area was the most obvious habitat variable to record, and seems to be a reliable indicator of the suitability of the habitat for many ant 
species on tropical Pacific islands, with some species occurring almost exclusively in disturbed areas and others in undisturbed areas (Greenslade and Greenslade 1977, Perrault 1988).

Species were identified according to the species concepts in Wilson and Taylor's (1967a) key, except that Tetramorium taxonomy follows Bolton (1977, 1979). P. S. Ward provided assistance in identification of specimens. Reference specimens from my collection have been deposited in the Bohart Museum of Entomology at U. C. Davis, and at the Museum of Comparative Zoology at Harvard.

I constructed species-effort curves for each island to illustrate the thoroughness of my censuses. Since some rare and/or localized species may have been missed, I used the following first-order jackknife estimator derived by Heltshe and Forrester (1983) to estimate the total ant species richness of each island:

$\mathrm{S}=\mathrm{s}+\mathrm{r}(\mathrm{n}-1) / \mathrm{n}$

where $\mathbf{S}$ is the predicted species richness, $\mathbf{S}$ is the observed species richness, $r$ is the number of species present at only one site, and $\mathrm{n}$ is the total number of sites collected. Palmer $(1990,1991)$ reviewed eight different estimators of species richness by extrapolation, and found the first-order jackknife to be the most precise. Palmer also found this estimator to be conservative, in that it has a tendency to underestimate true species richness. I also constructed $95 \%$ confidence intervals based on the variance of this estimator (Heltshe and Forrester 1983) for each island.

To elucidate the importance of negative interspecific interactions on observed ant species distribution patterns, I conducted chi-square tests of association on all possible pairwise combinations of species for each island, excluding rare species. Rare species were defined as species which occurred at fewer than four sample sites. I also performed a variance-ratio test (Schluter 1984) to determine the overall net association among all species on each island.

To test the significance of specified regression coefficients in the multiple regression analyses, a partial F-test was used (Neter et al. 1985).

\section{Results and discussion}

\section{Observed total species richness}

I found that many more species of ants exist on the islands surveyed than has previously been reported in the literature. Wilson and Taylor (1967a) listed 7 ant species from Bora Bora, 6 from Huahine, and 16 from Moorea. Wheeler (1936) recorded an additional 3 species from Huahine that were not included by
Wilson and Taylor, bringing the total number of species known in 1967 on Huahine to 9 (Appendix 1). My collections revealed the presence of 30 ant species on Bora Bora, 33 on Huahine and 36 on Moorea, increasing the known ant species richnesses on these islands by factors of $4.3,3.7$ and 2.3 , respectively. (See Appendix 2 for a list of all species, their distributions among the islands, frequencies of occurrence and origins.) Bolton's (1979) split of Tetramorium simillimum (F. Smith) into $T$. simillimum and $T$. caldarium (Roger) does cause an inflation in my observed species richnesses for all three islands relative to Wilson and Taylor's (1967a) numbers, but only by one species. With two exceptions, all species recorded from previous surveys were found to still be present (see below).

All of the species found are known from other islands in Polynesia and are included in Wilson and Taylor's (1967a) monograph, with the exception of Ponera bableti Perrault, Ponera sp. A and Pachycondyla cf. testacea. Thus, as has been the case in previous collections of remote Polynesian islands, no certain endemic species were found (Wilson and Taylor 1967a, Perrault 1988, Reimer et al. 1990), but the status of the three species listed above is uncertain.

\section{Estimated total species richness}

A number of species were very rare and/or localized. For example, on Moorea, where I collected from 153 different sites, two species were represented by only a single specimen from a single site. In addition, three species were found at only two sites, and one species was found at only three sites. On Bora Bora and Huahine, where I collected from 26 and 29 sites respectively, six species on each island were found at only one site.

Species-effort curves for each island are given in Fig. 1. Although the curves rose fairly steeply and began to level off relatively quickly, they never reached a definite asymptote, because of the existence of rare and/or localized species. This suggests the existence of some small number of additional, yet undiscovered species. Estimated species richnesses, based on the first-order jackknife estimator (Heltshe and Forrester 1983), on Bora Bora, Huahine and Moorea were 36,39 and 39 , respectively. Confidence intervals $(95 \%)$ were: $(30.6,41.0)$ for Bora Bora, $(33.6,44.0)$ for Huahine, and $(35.6,42.4)$ for Moorea. The relatively wide confidence intervals (especially for Bora Bora and Huahine, where fewer sites were sampled) resulted from the sensitivity of this estimator to the number of species found at a single sample site. 


\section{Distribution of species on islands}

Altitudinal stratification of ant species was not observed. With a single exception, all species were found within $10 \mathrm{~m}$ of sea level, although some species were more common in the higher elevations. Pheidole sexspinosa was not found $<100 \mathrm{~m}$. Upper elevational limits varied by species and ranged from $250 \mathrm{~m}$ to 899 $\mathrm{m}$ (peak of Mt Rotui, the second highest peak on Moorea) (Morrison 1995).

Proportionately more sites were sampled at lower elevations, because 1) more land area falls in the lower elevation categories as a result of the irregular conical shape of the islands, and 2) higher elevations are generally inaccessible. However, the observed general pattern is probably not simply an artifact of unequal sampling effort. One factor contributing to the pattern is that many species (e.g. Solenopsis geminata [Fabricius]) are known to be very closely associated with man and/or disturbed habitats (Perrault 1988, Reimer et al. 1990, Morrison 1996). Since most of the human population resides in the lower elevations, and most habitats dis-

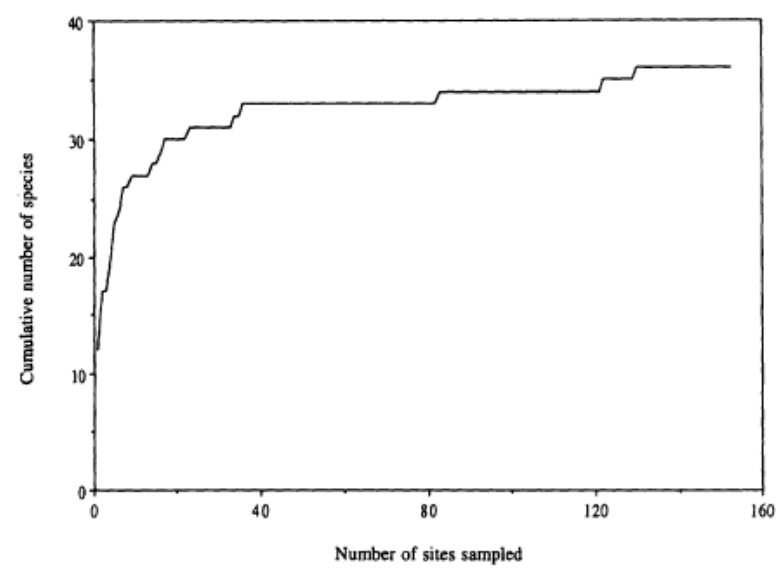

(a)

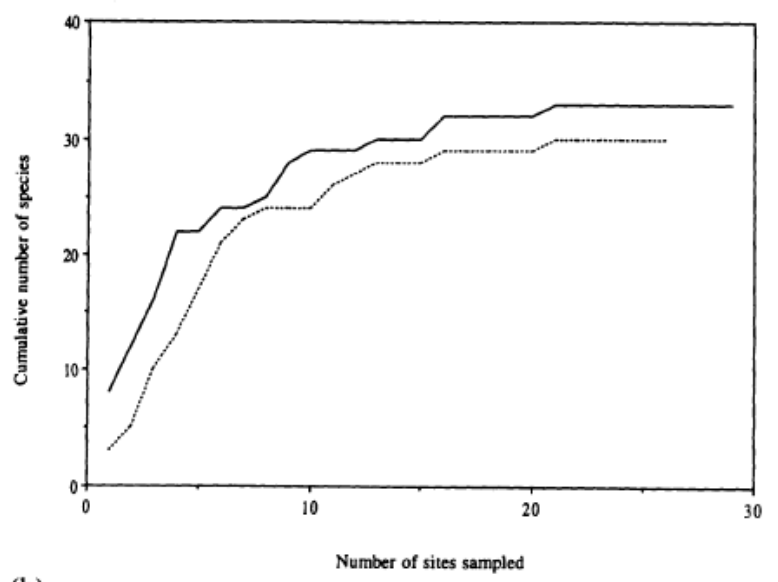

(b)

Fig. 1. Species-effort curves for a) Moorea, b) Huahine (straight line) and Bora Bora (dashed line). Note the difference in scale on the $\mathrm{X}$-axes.
Table 1. Values of $\mathrm{z}$ for Pacific archipelagos thoroughly surveyed for ants.

\begin{tabular}{lccc}
\hline Archipelago & Number of islands & $z$ & $r^{2}$ \\
\hline Solomon & 6 & 0.119 & 0.62 \\
Samoa & 3 & 0.100 & 0.28 \\
Hawaii & 6 & 0.164 & 0.52 \\
Society & 9 & 0.166 & 0.95 \\
Futuna and Wallis & 6 & 0.170 & 0.66 \\
\hline All & 30 & 0.144 & 0.81 \\
\hline
\end{tabular}

turbed by man are in the lower elevations, less suitable habitat exists in the higher elevations for the more anthropophilous tramp species. This same general pattern has also been observed for ants on the neighboring, island of Tahiti (Perrault 1988), and documented on the Hawaiian islands (Gillespie and Reimer 1993, their Fig. 1; Reimer 1994, his Table 1).

\section{Tests of species association}

Chi-square tests $(\mathrm{p}<0.05, \mathrm{DF}=1)$ of all possible pairwise combinations of species (except rare species) yielded the following results: On Bora Bora, 25 species occurred at more than three sites, and out of 231 potential interspecific interactions, 3 were significantly negative and 7 were significantly positive. On Huahine, 25 species occurred at more than three sites, and out of 300 possible interactions, 16 were significantly negative and 23 were significantly positive. On Moorea, 29 species found at more than three sites yielded 406 possible interactions, 57 of which were significantly negative and 75 of which were significantly positive.

Since so many comparisons are being made simultaneously, the chance of a type one error is no longer 0.05 . In fact, we would expect more than 10 significant interactions by chance alone using a critical value of 3.841 and doing over 200 simultaneous tests. Thus, it is not the absolute number of "significant" interactions that is of importance, but the proportion of positive vs. negative interactions whose chi-square statistic exceeds some critical value (in this case, 3.841 ). On all three islands, the number of "significant" positive interactions exceeded the number of "significant" negative interactions.

A simultaneous test of species association when the number of species exceeds two is due to Schluter (1984). This "variance-ratio" test compares the observed variance in the total species number of samples with the expected variance under a null hypothesis of no species association. This technique allows the calculation of a statistic which is chi-square distributed, so a meaningful probability can be assigned to the outcome. For all three islands, the variance-ratio test revealed a net positive interaction among all ant species. This net positive interaction was significant only on Huahine, 
however $(0.025<\mathrm{p}<0.05)$. Thus, this technique yielded comparable information to the multiple pairwise tests, pointing to a prevalence of positive interspecific interactions among the ants inhabiting these islands.

The preceding tests concern species associations within islands. As far as complementary distributions of species among islands is concerned, there was no evidence of it at all. Bora Bora, Huahine and Moorea displayed a perfect nested distribution pattern, with each island containing all the species of the next smaller size island plus some additional species (see Appendix 2, Island distribution column).

\section{Comparison with earlier surveys}

An important question that arises when comparing my survey of the three Society islands with earlier surveys of these same islands (summarized by Wilson and Taylor 1967a) is whether the earlier surveys were incomplete and missed species, or if ants have continued to immigrate over the intervening years. Although it is impossible to answer this question conclusively, it is worth considering the available, albeit anecdotal, evidence. Previous collections in the area date from 1906 to 1955 (see Appendix 1), allowing at least 36 years for ants to have immigrated before my first survey in 1991. Ants have certainly had opportunities to migrate in this time period. For example, at least two large ferry boats travel to the major islands in the Society group on a weekly basis, carrying cargo which would accommodate stow-away ants. (I have personally observed a colony of Solenopsis geminata apparently making its residence in a ferry boat traveling between Moorea and Tahiti).

However, I believe most of the species present today on the islands were also there during the first part of this century, and simply overlooked by the early collectors. Unfortunately, it cannot be conclusively determined from the published records how much time and/or effort the early collectors expended searching for ants, but from the few location records published, it seems their efforts were rather restricted (see references in Appendix 1). If this is true, species which are localized or cryptic would have escaped the notice of the early collectors to a large degree.

I determined the present-day percentage of ants on each island which are cryptic and/or localized. "Cryptic" species are those which would be unapparent to the casual collector because they are found primarily in the leaf litter, under large rocks and logs, in the soil, and/or their coloration often matches that of their surroundings. Species I consider to be cryptic are Anochetus graeffei Mayr, Quadristruma emmae (Emery), Strumigenys godeffroyi Mayr, Strumigenys rogeri Emery, Pachycondyla cf. testacea and Trichoscapa membrani- fera Emery. Species considered as localized are those found at $<10 \%$ of the sampled sites on Huahine and Bora Bora, and at $<5 \%$ of the sampled sites on Moorea.

The percentages of localized and/or cryptic species that I found on Moorea, Huahine and Bora Bora are $29 \%, 31 \%$, and $34 \%$, respectively. The percentages of species which I consider as localized and/or cryptic that were reported by earlier collectors are $0 \%, 22 \%$, and $0 \%$ (again for Moorea, Huahine and Bora Bora, respectively). (For the purpose of this analysis, I consider Tetramorium simillimum and $T$. caldarium as one species, so that changes in taxonomy have no effect in comparing the percentages). This analysis indicates that either the earlier surveys were incomplete, or that disproportionate numbers of cryptic and localized species have immigrated within the last few decades. There is no obvious reason for the latter phenomenon.

\section{Species-area relationships}

Wilson and Taylor (1967b, their Fig. 1) presented a species-area graph for ants on Polynesian islands. The islands included fell into two main groups, a lower group representing the majority of the islands, and an upper group of five outliers representing the three Samoan islands, Tahiti and Oahu. Wilson and Taylor (1967a, b) attributed the relatively high species richness of the Samoan islands to the presence of a proportionately large number of native and endemic species, as opposed to the predominantly tramp faunas found on the other, more remote islands. The high species richnesses of Oahu, and to a lesser degree Tahiti, could be explained in part by the amount of foreign traffic passing through their ports, allowing more opportunities for immigration.

Figure 2 shows the species-area relationship for the same islands when data from records published after 1967 (Huddleston and Fluker 1968, Perrault 1988, Reimer et al. 1990 and pers. comm.), along with my own data, are added. Again, the points fall into two groups, an upper and a lower one. But without excep. tion all the upper points represent islands which were surveyed thoroughly by some myrmecologist(s) over a relatively long period of time: Taylor spent five weeks collecting intensively on the three Samoan islands (Wilson and Taylor 1967a), Huddleston and Fluker collected from 169 sites over a 2-year period on the six major Hawaiian islands (Huddleston and Fluker 1968), Reimer has surveyed the ants of the Hawaiian islands for a number of years (Reimer et al. 1990 and pers. comm.), Perrault collected ants from Tahiti $>10$ years (Perrault 1988), and I spent a total of 14 weeks intensively collecting from $>200$ sites overall on Bora Bora, Huahine and Moorea. 


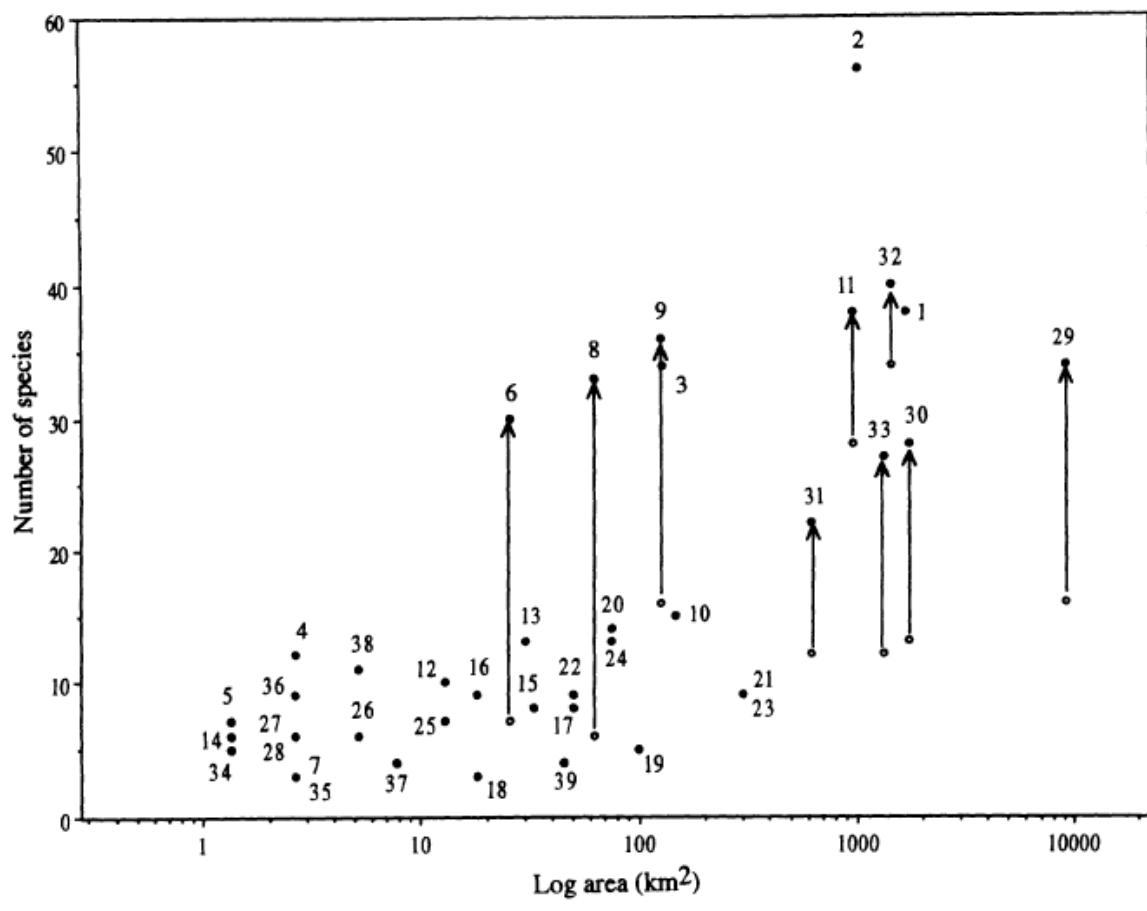

Fig. 2. Species-area relationship for Polynesian islands. Open circles represent pre-1967 species numbers on islands which have since been thoroughly surveyed. Arrows indicate the increase in species numbers resulting from the more recent surveys. Samoa: (1) Savai'i, (2) Upolu, (3) Tutuila; Tokelau: (4)

Fakaofo; Danger Islands: (5) Motu Kotawa; Society Islands: (6) Bora Bora, (7) Mehetia, (8) Huahine, (9) Moorea, (10) Raiatea, (11) Tahiti; Austral Islands: (12) Rimatara, (13) Raivavae,

(14) Maria Island, NE Islet,

(15) Rapa; Gambier Islands:

(16) Manga Reva, (17) Eiao,

(18) Hatutu, (19) Ua Pu,

(20) Ua Huka, (21) Hiva

Oa, (22) Tahuata, (23) Nuka Hiva, (24) Fatu Hiva, (25)

Mohotane; Pitcairn: (26);

Henderson: (27); Flint: (28);

Hawaiian: (29) Hawaii, (30)

Maui, (31) Molokai, (32)

Oahu, (33) Kauai, (34)

Nihoa, (35) French Frigate

Shoals, (36) Laysan, (37)

Wake, (38) Midway, (39)

Kure (Ocean)

To further investigate the importance of sampling effort on known ant species composition, I performed a multiple regression of species number on sampling effort and $\log$ (island area). Sampling effort was defined as the number of collectors known to have visited each island. Data were obtained from Wilson and Taylor (1967a), and updated to reflect collections made since 1967. Although the number of man-hours or even the number of days spent collecting would be a much better estimate of collecting intensity, this information is not available. The Hawaiian islands were deleted from this analysis because the number of collectors that visited the various islands is not known with certainty (Wilson and Taylor 1967a). Sampling effort was highly significant, but area was not significant (partial F-test; $\mathrm{p}=$ 0.0001 for sampling effort, $p=0.36$ for area). When sampling effort was the only independent variable, it explained $75 \%$ of the variation in species number. In comparison, $\mathrm{r}^{2}$ for the multiple regression was only 0.76. Logarithmic transformations of species number and/or sampling effort did not change the significance of either independent variable when a partial F-test was used $(\mathrm{p}<0.05)$. Thus, sampling effort appears to be a major factor influencing the known ant species richness of an island, even when such an admittedly crude measure as number of collectors is used.
In addition to the Samoan, Society, and Hawaiian islands in Polynesia which have been thoroughly surveyed for ants, two other island groups farther west have also been surveyed relatively thoroughly by myrmecologists: Futuna and the Wallis islands (Wilson and Hunt 1967), and a number of the Solomon islands (Mann 1919). Figure 3 shows the species-area relationship for the islands of these five Pacific archipelagoes which have been surveyed (relatively) thoroughly for ants. Table 1 reveals that the z-values (slope of the regression line on a log-log plot) for the five archipelagos included in this graph all ranged between 0.100 and 0.170 .

The observed z-values are below the 0.20 to 0.35 range commonly observed in insular species-area relationships (MacArthur and Wilson 1967). However, zvalues have been observed to decrease with increasing isolation of an archipelago (Hamilton and Armstrong 1965, Schoener 1976). Schoener (1976) attributes the lower z-values of more distant archipelagoes to the fact that the slope of the species-area curve depends on the source pool size, which will be smaller for more isolated archipelagos. There is indeed a very limited source pool for Polynesian ants (Wilson and Taylor 1967a). Another potential factor is that many species are tramps which can survive in very marginal or highly disturbed 
Fig. 3. Species-area relationship for the more thoroughly surveyed Pacific islands. Closed squares Solomons: (1) Ugi, (2)

Malapaina, (3) Ysabel, (4)

Florida, (5) Malaita, (6) San

Cristobal; Open squares -

Futuna and Wallis: (7)

Futuna, (8) Uvea, (9)

Nukuifala, (10) Nukuione,

(11) Nuku Tapu, (12)

Tekeviki; Open circles -

Samoa: (13) Savaii, (14)

Upolu, (15) Tutuila; Closed

circles - Society Islands:

(16) Bora Bora, (17)

Huahine, (18) Moorea, (19)

Tahiti, (20) Bora Bora Islet,

(21) Irioa, (22) Ahi, (23)

Tiahura, (24) Fareone;

Closed triangles - Hawaiian

Islands: (25) Hawaii, (26)

Maui, (27) Molokai, (28)

Oahu, (29) Kauai, (30)

Lanai.

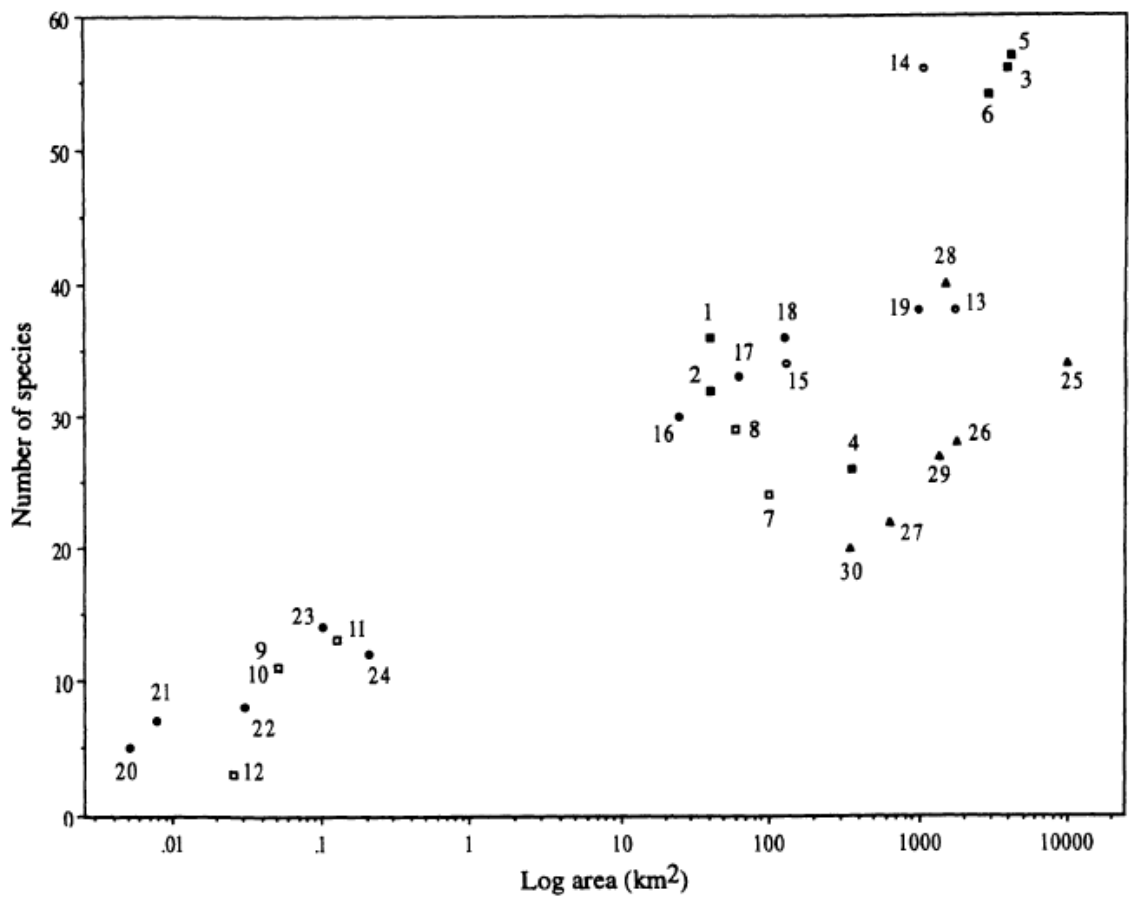

habitats, and so can exist on relatively small islands. On the islands I surveyed, for example, no species were limited to the higher, relatively undisturbed interiors of the islands.

The overall z-value for the Pacific islands included in Fig. 3 is $0.144\left(r^{2}=0.81\right)$. I also fit a quadratic regression to the data of Fig. 3, since area varies over six orders of magnitude. The quadratic regression $\left(\mathrm{r}^{2}=\right.$ 0.83 ) fit the data significantly better than the linear regression $\left(r^{2}=0.81 ; p=0.0415\right.$, partial F-test).

It can be noted in Fig. 3 that some of the Solomon islands, which are closest to the Indo-Australian mainland, contain relatively high ant species numbers for their areas, while five of the Hawaiian islands, which are the most remote (from any mainland) contain the lowest ant species numbers for their areas. Yet this trend of fewer species on more distant islands does not hold for the other archipelagoes in general. To determine whether this distance effect is significant, I conducted a multiple regression of species number on island area and distance. Table 2 shows the results for various transformations of the variables. Area was always a highly significant regression coefficient, but the significance of distance varied depending on the regression model used.

Even on these "thoroughly" surveyed islands, differences in collecting intensity among investigators on different islands should be taken into account (and are usually unknown) when considering this relationship. Mann (1919), for example, admitted that his records from the Solomons probably did not include all species which were actually present there. Thus, more complete collections from these islands may shift some data points up and increase the significance of the distance effect. The other archipelagos, however, appear to have been collected thoroughly enough that additional collecting effort would cause no major changes. What can be said is that, at present, there is a trend of more remote Polynesian islands having fewer ant species (on an areal basis) than less remote Pacific islands, but the statistical significance of this distance effect is equivocal. Additional, thorough sampling of some of the less remote Pacific islands is needed before any definite conclusions are drawn

Table 2. Multiple regressions of species number on island area and distance for Pacific islands thoroughly surveyed for ants. Abbreviations: $\mathrm{S}=$ species; $\mathrm{A}=$ area; $\mathrm{D}=$ distance.

\begin{tabular}{llccc}
\hline \multirow{2}{*}{$\begin{array}{l}\text { Dependent } \\
\text { variable }\end{array}$} & $\begin{array}{c}\text { Independent } \\
\text { variables }\end{array}$ & $\begin{array}{c}\text { Overall } \\
\mathrm{r}^{2}\end{array}$ & & \multicolumn{2}{c}{$\mathrm{p}$} \\
\cline { 4 - 5 } & & & Area & Distance \\
\hline $\mathrm{S}$ & $\log \mathrm{A}, \mathrm{D}$ & 0.79 & 0.0001 & 0.0042 \\
$\log \mathrm{S}$ & $\log \mathrm{A}, \mathrm{D}$ & 0.83 & 0.0001 & 0.0618 \\
$\mathrm{~S}$ & $\log \mathrm{A}, \log \mathrm{D}$ & 0.78 & 0.0001 & 0.0070 \\
$\log \mathrm{S}$ & $\log \mathrm{A}, \log \mathrm{D}$ & 0.82 & 0.0001 & 0.0998 \\
\hline
\end{tabular}




\section{A re-evaluation of the effect of competition on ant species distributions}

Wilson and Taylor (1967b) presented three "lines of evidence" to support their contention that the relatively low ant species numbers they reported on Polynesian islands had stabilized to a large degree through competitive interactions. It is worthwhile to re-examine these in light of more recent work.

1) Wilson and Taylor (1967a) listed 35 tramp species which are widely dispersed over Polynesia by human commerce (not including species which were intercepted in quarantine and never established). Only a relatively small fraction were known to exist on any given island at a time (usually $<25 \%$ ), suggesting an upper limit to the number of tramp species which could co-exist on an island. However, more in-depth surveys conducted since 1967 have found a larger number of tramp species co-existing on the islands studied. For example, the number of tramp species reported from Moorea, Huahine and Bora Bora by Wilson and Taylor (1967a) was 10,4 , and 6 respectively. The number of tramp species I found on these same islands was 21, 20 and 19 (again for Moorea, Huahine and Bora Bora respectively). Similar increases in the number of known tramp species have been reported on Tahiti (Perrault 1988) and Hawaii (Reimer et al. 1990).

The known species pool of tramps has also increased since 1967, but by only four species: In Hawaii, Cardiocondyla venustula Wheeler (listed as Cardiocondyla "a" by Huddleston and Fluker [1968], [Reimer pers. comm.]), Ochetellus glaber (Mayr) (formerly Iridomyrmex glaber, Beardsley 1980), and Pseudomyrmex gracilis (Roger) (a native new world species recently introduced to Hawaii; Beardsley 1979), have been discovered. I found one apparent new tramp species in the Society islands: Pachycondyla cf. testacea. Thus, the maximum known source pool of tramps is 39 species.

However, the number of tramp species which is actually available to colonize the islands in the Society Archipelago may be considerably less. For example, a number of the 39 species which comprise the tramp species pool are very limited in their distribution in Polynesia and may have never had a chance to reach the islands of this study. For example, 8 of the 39 species are known only from the Hawaiian islands. Because of the extensive foreign trade going through Honolulu, it seems that a number of ant species have been able to colonize Hawaii, but have not been able to reach other islands which have less active foreign commerce.

Also, some records are doubtful and may be in error. For example, Plagiolepis exigua Forel is recorded in Polynesia from Hawaii only. However, no specimens exist of this species in any collections, and it is very probable it never was in Hawaii, but was confused with the morphologically similar Plagiolepis alluaudi Forel (Wilson and Taylor 1967a, Reimer pers. comm.). Tetramorium caespitum (Linné) was recorded only once in Polynesia, from Tahiti by Wheeler (1936), but this species, even if present at one time on Tahiti probably never established itself because it is a temperate-zone species (Perrault 1988).

Finally, some species may have been able to reach a number of islands, but not have been able to colonize because of the absence of the appropriate habitat. For example, Linepithema humile (Mayr) (formerly Iridomyrmex humilis) is most successful in temperate areas. In Polynesia, it is known only from Hawaii, at elevations > $900 \mathrm{~m}$ (Gillespie and Reimer 1993, Reimer 1994). Lower islands may not provide suitable habitat for this species.

Thus, given the relatively small size of the "effective" tramp species pool (comprised of the tramp species which really do exist in Polynesia, have had opportunities to reach the Society Islands, and found suitable habitat present) in comparison to the number of tramp species actually found on the islands surveyed, it does not seem necessary to posit that ant species numbers have been limited by competition. It seems rather that most species which had the opportunity to make the journey and found the appropriate habitat present were able to colonize and exist there today.

The known pool of all species has also increased by a small amount, from 67 species listed by Wilson and Taylor (1967a) to 76 species (Morrison 1995). However, the "effective" source pool of all species may be considerably lower, for the same reasons listed above. As was the case when considering tramp species alone, richnesses of all species on the islands censused are c. $50 \%$ of the total source pool.

2) Wilson and Taylor (1967b) stated that because of negative interspecific interactions (i.e. competition), some groups of ecologically similar species displayed complementary distribution patterns. I found this to be true for Pheidole fervens Fr. Smith, Pheidole oceanica Mayr, and Solenopsis geminata (the numerically and behaviorally dominant species in the communities in which they occur), which displayed a complementary distribution pattern within islands (Morrison 1996). However, no such pattern was evident in my data for any other groups. Wilson and Taylor (1967b) stated that complementary patterns occurred between Cardiocondyla emeryi Forel and Cardiocondyla nuda (Mayr), and between Paratrechina bourbonica and Paratrechina vaga, but did not present any data to support this assertion. Both species pairs co-existed on all three islands I censused. Analysis of their distribution patterns among sites by chi-square tests $(\mathrm{DF}=1)$ revealed that no species pairs demonstrated a significant negative association on any island, and moreover a significant positive association between C. emeryi and C. nuda was observed on Moorea $(p<0.001)$. Perrault $(1988)$ 
also noted the tendency of $C$. emeryi and $C$. nuda to coexist on Tahiti.

Overall, on the islands I censused, pairwise $\chi^{2}$ tests and variance-ratio tests of species associations demonstrated a predominance of net positive interactions among species (see Results).

Although competition has been documented among many of the ant species which inhabit these islands (Morrison 1996), it does not appear to be strong enough in the Society archipelago for species to exclude each other from whole islands, or even from communities within islands, with at least one notable exception ( $P$. fervens, $P$. oceanica and $S$. geminata). Thus the complementary distribution pattern discussed by Wilson and Taylor (1967b) seems to be the exception, rather than the rule, at least in the Society archipelago. The positive interspecific interactions observed probably result from shared habitat affinities rather than some type of mutualism or other symbiosis, although little data exists at present to test definitively this hypothesis.

3) Wilson and Taylor (1967b) stated that some tramp species have unstable populations, and hypothesized that population fluctuations may be large enough to cause extinctions of species on islands. One way to evaluate this is to compare the species composition of ants on an island at present to some time in the past, to see if any species turnover has occurred. Since the current survey revealed the presence of many more species than previous collections, either 1) the previous collections were not very thorough, or 2) many species have immigrated within the past few decades. Thus, it is not possible to determine immigrations with certainty, but extinctions can be observed.

All previous collection records from Bora Bora, Huahine and Moorea are given in Appendix 1. Of the seven species known from past collections on Bora Bora, all are still present except one, Pheidole oceanica. All nine species collected previously on Huahine are still present. On Moorea, out of 16 species reported in previous collections, only one, Monomorium pharaonis (Linné), is not now present. (This record is questionable because $M$. pharaonis was only recorded once on Moorea [Wheeler 1908], and never on any other islands in the Society group). It should be noted that the collection records date back almost 90 years in some cases. Yet overall, a maximum of only 2 extinctions out of a possible 32 have occurred. This is especially remarkable if immigration rates have been as high as the results of earlier surveys would indicate.

\section{Conclusion}

In summary, surveys of Polynesian islands conducted since 1967 (which are almost certainly more thorough than most pre-1967 surveys) have revealed many more ants to exist on these islands than previously thought. Figure 3 reveals that while some of the more remote, eastern Polynesian islands have relatively fewer ant species than some islands in western Polynesia or Melanesia, this pattern is obscured by a large degree of scatter in the data points, and the statistical significance of the effect of distance on ant species numbers depends upon the regression model used. Thus, it is questionable whether, on an areal basis, the more remote Polynesian islands lacking a native fauna (i.e. the Society and Hawaiian Archipelagos) are really depauperate compared to less remote islands of the Pacific which have endemic species. Thorough sampling of additional, less remote Pacific islands is necessary to resolve this issue.

It is possible that the increase in ant species numbers observed on recently surveyed islands is due to immigrations of ants since the earlier surveys, or more in-depth surveys since 1967 , or both. The fact that: 1) very few localized or cryptic species were found by the early collectors, and 2) all islands known to have been thoroughly surveyed by some myrmecologist(s) contain relatively higher species numbers than other islands (and often by a high factor, Fig. 2), suggests that most species were probably present during the time of the earlier surveys but simply not recorded.

Interspecific competition, while it is an important factor in community organization on these islands, does not seem to be intense enough to influence the actual distribution of species within or among islands, with one important exception: the $P$. fervens $-P$. oceanica- $S$. geminata interaction (Morrison 1996).

It appears Wilson and Taylor's (1967b) theories of evolutionary increase in the Polynesian ant fauna were based on an incomplete data set for the region. Wilson and Taylor predicted a potential evolutionary increase in species numbers of from 1.5 to 2 times the known 1967 species richnesses, based on areal relationships with other, less remote islands (Wilson and Taylor 1967b, their Fig. 5). Of the four Society and five Hawaiian islands which have been more thoroughly surveyed since 1967, the average increase in species richness is 2.3 times the 1967 estimate. Thus, ant species richnesses on the islands more thoroughly surveyed are now about where Wilson and Taylor expected them to be (based on their size), but with only a small increase in the known species pool and without any evolutionary changes having occurred.

Acknowledgments - This work was funded by grants from the Center for Population Biology at U.C. Davis; Jastro-Shields Research Scholarships; Grants-in-Aid of Research from Sigma $\mathrm{Xi}$, The Scientific Research Society; and an NSF Graduate Fellowship to the author. Much of this work was accomplished while I was a resident at U.C. Berkeley's R. B. Gump South Pacific Biological Research Station (contribution \# 30). I am indebted to R. Steger and F. Murphy of the Gump Station for their aid in the field. I thank P. S. Ward for assistance in identifying the ants. The comments of $\mathrm{T}$. W. 
Schoener, P. S. Ward, and R. Karban improved earlier versions of this manuscript.

\section{References}

Beardsley, J. W. 1979. Note on Pseudomyrmex gracilis mexicanus (Roger). - Proc. Hawn. Ent. Soc. 23: 23.

- 1980. Note on Iridomyrmex glaber (Mayr). - Proc. Hawn. Ent. Soc. 23: 186

Bolton, B. 1977. The ant tribe Tetramoriini (Hymenoptera: Formicidae). The genus Tetramorium Mayr in the Oriental and Indo-Australian regions, and in Australia. - Bull. Br. Mus. Nat. Hist. Entomol. 36: 67-151

- 1979. The ant tribe Tetramoriini (Hymenoptera: Formicidae). The genus Tetramorium Mayr in the Malagasy region and in the New World. - Bull. Br. Mus. Nat. Hist. Entomol. 38: 129-181.

Cheeseman, L. E. and Crawley, W. C. 1928. A contribution towards the insect fauna of French Oceania. Part III. Formicidae. - Ann. Mag. Nat. Hist. 10th Series 2: 514-525.

Gabrie, C. and Salvat, B. 1985. General features of French Polynesian islands and their coral reefs. - In: Delesalle, B., Galzin, R. and Salvat B. (eds), Fifth Int. coral reef congr. Tahiti, 1985. Vol. 1: French Polynesian coral reefs, pp. $1-16$.

Galzin, R. and Pointier, J. P. 1985. Moorea Island, Society Archipelago. - In: Delesalle, B., Galzin, R. and Salvat B. (eds), Fifth international coral reef congr. Tahiti, 1985. Vol. 1: French Polynesian coral reefs, pp. 73-102.

Gillespie, R. G. and Reimer, N. J. 1993. The effect of alien predatory ants (Hymenoptera: Formicidae) on Hawaiian endemic spiders (Araneae: Tetragnathidae). - Pac. Sci. 47: $21-33$.

Greenslade, P. J. M. and Greenslade, P. 1977. Some effects of vegetation cover and disturbance on a tropical ant fauna. - Insectes Soc. 24: 163-182.

Hamilton, T. H. and Armstrong, N. E. 1965. Environmental determination of insular variation in bird species abundance in the Gulf of Guinea. - Nature 207: 148-151.

Heltshe, J. F. and Forrester, N. E. 1983. Estimating species richness using the jackknife procedure. - Biometrics 39: $1-11$.

Holldobler, B. and Wilson, E. O. 1990. The Ants. - Belknap Press, Cambridge, MA.

Huddleston, E. W. and Fluker, S. S. 1968. Distribution of ant species of Hawaii. - Proc. Hawn. Ent. Soc. 20: 45-69.

MacArthur, R. H. and Wilson, E. O. 1967. The theory of island biogeography. - Princeton Univ. Press.

Mann, W. M. 1919. The ants of the British Solomon Islands. - Bull. Mus. Comp. Zool. 63: 273-291.
Morrison, L. W. 1995. The island biogeography and metapopulation dynamics of ants. - Ph.D. dissertation, Univ. of California, Davis, CA.

- 1996. Community organization in a recently assembled fauna: the case of Polynesian ants. - Oecologica: in press.

Neter, J., Wasserman, W. and Kutner, M. H. 1985. Applied linear statistical models. 2nd ed. - Irwin, Homewood, Illinois.

Palmer, M. W. 1990. The estimation of species richness by extrapolation. - Ecology 71: 1195-1198.

- 1991. Estimating species richness: the second-order jackknife reconsidered. - Ecology 72: 1512-1513.

Perrault, G. H. 1988. Les fourmis de Tahiti. - Bull. Soc. Zool. Fr. 112: 429-445.

Reimer, N. J. 1994. Distribution and impact of alien ants in vulnerable Hawaiian ecosystems. - In: Williams, D. F (ed.), Exotic ants: Biology, impact and control of introduced species. Westview Press, Boulder, Colorado, pp. $11-22$

Reimer, N., Beardsley, J. W. and Jahn, G. 1990. Pest ants in the Hawaiian Islands. - In: Van der Meer, R. K., Jaffe, K. and Cedeno, A. (eds), Applied myrmecology: A world perspective. Westview Press, Boulder, Colorado, pp. 4050

Romero, H. and Jaffe, K. 1989. A comparison of methods for sampling ants (Hymenoptera, Formicidae) in savannahs. Biotropica 21: $348-352$.

Schluter, D. 1984. A variance test for detecting species associations, with some example applications. - Ecology 65 $998-1005$.

Schoener, T. W. 1976. The species-area relation within archipelagos: models and evidence from island land birds. - Proc. 16th Int. Ornith. Congr., Canberra, pp. 629-642.

Ward, P. S. 1987. Distribution of the introduced Argentine an (Iridomyrmex humilis) in natural habitats of the Lower Sacramento Valley and its effects on the indigenous ant fauna. - Hilgardia 55: 1-16.

Wheeler, W. M. 1908. Ants from Moorea, Society Islands. Am. Mus. Nat. Hist. Bull. (NY) 24: 165-167.

- 1935. Ants from the Society Islands. - Bull. B. P. Bishop Mus. 113: 13-19.

- 1936. Ants from the Society, Austral, Tuamotu and Mangareva Islands. - B. P. Bishop Mus., Occ. Pap. 12: 3-17.

Wilson, E. O. and Hunt, J. G. L. 1967. Ant fauna of Futuna and Wallis Islands, stepping stones to Polynesia. - Pac. Insects 9: $563-584$.

- and Taylor, R. W. 1967a. The ants of Polynesia (Hymenoptera: Formicidae). - Pac. Insects Monogr. 14: 1109.

- and Taylor, R. W. 1967b. An estimate of the potential evolutionary increase in species density in the Polynesian ant fauna. - Evolution 21: 1-10.

Appendix 1. Summary of pre-1967 collection records from the literature for Moorea, Huahine and Bora Bora. The dates given under the "Reference" heading refer to when the specimens were actually collected. (Except in parentheses: no collection date could be found for these records and dates given refer to when the record was first published.) The collector's name and literature citation are listed in the "Authorities" section.

\begin{tabular}{|c|c|}
\hline Species & Reference \\
\hline & \\
\hline $\begin{array}{l}\text { Pheidole fervens } \mathrm{Fr} \text {. Smith } \\
\text { Pheidole oceanica Mayr }\end{array}$ & $1925^{A},(1935)^{B}, 1934^{C}$ \\
\hline Pheidole umbonata Mayr & $1934^{\mathrm{C}}, 193 \mathrm{~J}^{-1}$ \\
\hline Cardiocondyla emeryi Forel & $1934^{\mathrm{C}}, 1955^{\mathrm{E}}$ \\
\hline Solenopsis geminata (Fabricius) & $1906-07^{\mathrm{F}}, 1925^{\mathrm{A}},(1935)^{\mathrm{D}}, 1934^{\mathrm{C}}, 1955^{\mathrm{E}}$ \\
\hline Monomorium floricola (Jerdon) & $1924^{\mathrm{G}}, 1934^{\mathrm{C}}$ \\
\hline Monomorium monomorium Bolton & $1934^{\mathrm{C}}, 1955^{\mathrm{E}}$ \\
\hline Monomorium pharaonis (Linne) & $1906-07^{\mathrm{F}}$ \\
\hline Tetramorium pacificum Mayr & $1906-07^{\mathrm{F}}, 1924^{\mathrm{G}},(1935)^{\mathrm{D}}, 1934^{\mathrm{C}}$ \\
\hline Tetramorium tonganum Mayr & $(1935)^{\mathrm{D}}, 1934^{\mathrm{C}}$ \\
\hline Tapinoma melanocephalum (Fabricius) & $1906-07^{\mathrm{F}}, 1925^{\mathrm{A}}, 1934^{\mathrm{C}}, 1955^{\mathrm{E}}$ \\
\hline
\end{tabular}


Appendix 1. (cont.)

\begin{tabular}{|c|c|c|}
\hline Species & & Reference \\
\hline $\begin{array}{l}\text { Technomyrmex albipes (Fr. Smith) } \\
\text { Anoplolepis longipes (Jerdon) } \\
\text { Plagiolepis alluaudi Forel } \\
\text { Paratrechina longicornis (Latreille) } \\
\text { Paratrechina vaga (Forel) }\end{array}$ & & $\begin{array}{l}1906-07^{\mathrm{F}}, 1925^{\mathrm{A}},(1935)^{\mathrm{D}} \\
1906-07^{\mathrm{F}}, 1934^{\mathrm{C}}, 1955^{\mathrm{E}} \\
1906-07^{\mathrm{F}},(1935)^{\mathrm{D}} \\
1906-07^{\mathrm{F}} \\
1906-07^{\mathrm{F}}, 1925^{\mathrm{A}}, 1934^{\mathrm{C}}\end{array}$ \\
\hline $\begin{array}{l}\text { Pheidole fervens } \text { Fr. Smith } \\
\text { Pheidole sexspinosa Mayr } \\
\text { Tetramorium pacificum Mayr } \\
\text { Tetramorium tonganum Mayr } \\
\text { Technomyrmex albipes (Fr. Smith) } \\
\text { Anoplolepis longipes (Jerdon) } \\
\text { Plagiolepis alluaudi Forel } \\
\text { Paratrechina bourbonica (Forel) } \\
\text { Paratrechina vaga (Forel) }\end{array}$ & Huahine & $\begin{array}{l}1926^{\mathrm{A}} \\
1934^{\mathrm{C}} \\
1934^{\mathrm{C}} \\
1934^{\mathrm{C}} \\
1934^{\mathrm{C}} \\
1955^{\mathrm{E}} \\
1925^{\mathrm{A}} \\
1955^{\mathrm{E}} \\
1934^{\mathrm{C}}\end{array}$ \\
\hline $\begin{array}{l}\text { 'Pheidole fervens } \text { Fr. Smith } \\
\text { Pheidole oceanica } \mathrm{Mayr} \\
\text { Cardiocondyla emeryi Forel } \\
\text { Monomorium floricola(Jerdon) } \\
\text { Tetramorium bicarinatum (Nylander) } \\
\text { Tetramorium simillimum (Fr. Smith) } \\
\text { Paratrechina longicornis (Latreille) } \\
\text { Paratrechina bourbonica (Forel) } \\
{ }^{2} \text { Anoplolepis longipes (Jerdon) }\end{array}$ & Bora Bora & $\begin{array}{l}1925^{\mathrm{H}} \text { (motu only) } \\
1908^{\mathrm{I}}, 1934^{\mathrm{C}} \\
1934^{\mathrm{C}} \\
1934^{\mathrm{C}} \\
1934^{\mathrm{C}} \\
1925^{\mathrm{H}} \\
1925^{\mathrm{H}} \\
1925^{\mathrm{H}} \\
1925^{\mathrm{A}}\end{array}$ \\
\hline
\end{tabular}

${ }^{1}$ This species was recorded from an islet on the barrier reef of Bora Bora, not on the main island. It was not included in Wilson and Taylor's (1967a) species count.

${ }^{2}$ Questionable. Listed as present on "all islands visited" by Cheeseman and Crawley (1928), which would include Bora Bora, but no specific locality was given for Bora Bora. Not included in Wilson and Taylor's (1967a) species count.

Authorities: A: collected by G. P. Wilder, first reported by Wheeler (1936). B: collected by H. M. Smith, first reported by Wheeler (1935). C: collected by E. C. Zimmerman, first reported by Wheeler (1936). D: collected by Adamson, first reported by Wheeler (1935). E: collected by "N.K.", first reported by Wilson and Taylor (1967). F: collected by G. A. McTavish, first reported by Wheeler (1908). G: unknown collector, first reported by Wilson and Taylor (1967). H: collected and first reported by Cheeseman and Crawley (1928). I: collected by H. E. Crampton, first reported by Wheeler (1935).

Appendix 2. List of species found, their distribution among the islands sampled, origin, and frequency of occurrence.

\begin{tabular}{|c|c|c|c|}
\hline Species & $\begin{array}{c}\text { Island } \\
\text { distribution }^{1}\end{array}$ & Origin $^{2}$ & $\begin{array}{l}\text { Freq. of } \\
\text { occurrence }^{3}\end{array}$ \\
\hline \multicolumn{4}{|l|}{ Ponerinae } \\
\hline Hypoponera opaciceps (Mayr) & BHM & TS & 5.29 \\
\hline Hypoponera punctatissima (Roger) & M & IA & 0.96 \\
\hline Anochetus graeffei Mayr & BHM & IA & 9.13 \\
\hline Pachycondyla cf. testacea Motschulsky & BHM & TS (?) & 14.42 \\
\hline Ponera bableti Perrault & $\mathrm{HM}$ & $?$ & 0.96 \\
\hline Ponera sp. A & $\mathbf{M}$ & $?$ & 0.48 \\
\hline \multicolumn{4}{|l|}{ Myrmicinae } \\
\hline Trichoscapa membranifera Emery & HM & TS & 1.44 \\
\hline Strumigenys godeffroyi Mayr & $\mathrm{BHM}$ & TS & 19.23 \\
\hline Strumigenys rogeri Emery & BHM & TS & 19.71 \\
\hline Quadristruma emmae (Emery) & $\mathrm{M}$ & TS & 0.48 \\
\hline Pheidole fervens Fr. Smith & BHM & IA & 51.44 \\
\hline Pheidole oceanica Mayr & $\mathrm{HM}$ & IA & 26.44 \\
\hline Pheidole umbonata Mayr & $\mathrm{BHM}$ & IA & 24.04 \\
\hline Pheidole sexspinosa Mayr & $\mathrm{BHM}$ & IA & 2.88 \\
\hline Cardiocondyla emeryi Forel & BHM & TS & 26.92 \\
\hline Cardiocondyla nuda (Mayr) & $\mathrm{BHM}$ & TS & 25.00 \\
\hline Cardiocondyla wroughtoni (Forel) & BHM & TS & 12.02 \\
\hline Solenopsis geminata (Fabricius) & BHM & TS & 27.88 \\
\hline Solenopsis papuana Emery & BHM & IA & 35.58 \\
\hline Monomorium floricola (Jerdon) & BHM & TS & 56.25 \\
\hline Monomorium monomorium Bolton & BHM & TS & 12.02 \\
\hline Monomorium talpa Emery & BHM & IA & 13.94 \\
\hline Tetramorium bicarinatum (Nylander) & $\mathrm{BHM}$ & TS & 21.63 \\
\hline Tetramorium caldarium (Roger) & BHM & TS & 1.92 \\
\hline Tetramorium pacificum (Mayr) & BHM & IA & 55.77 \\
\hline
\end{tabular}


Appendix 2. (cont.)

\begin{tabular}{|c|c|c|c|}
\hline Species & $\begin{array}{c}\text { Island } \\
\text { distribution }^{1}\end{array}$ & Origin $^{2}$ & $\begin{array}{l}\text { Freq. of } \\
\text { occurrence }^{3}\end{array}$ \\
\hline $\begin{array}{l}\text { Tetramorium simillimum }(\mathrm{F} . \mathrm{Smith}) \\
\text { Tetramorium tonganum } \mathrm{Mayr} \\
\text { Rogeria stigmatica } \text { Emery }\end{array}$ & $\begin{array}{l}\text { BHM } \\
\text { BHM } \\
\text { BHM }\end{array}$ & $\begin{array}{l}\text { TS } \\
\text { IA } \\
\text { IA }\end{array}$ & $\begin{array}{l}16.35 \\
10.58 \\
18.27\end{array}$ \\
\hline $\begin{array}{l}\text { Dolichoderinae } \\
\text { Tapinoma melanocephalum (Fabricius) } \\
\text { Tapinoma minutum Mayr } \\
\text { Technomyrmex albipes (Fr. Smith) }\end{array}$ & $\begin{array}{l}\text { BHM } \\
\text { BHM } \\
\text { BHM }\end{array}$ & $\begin{array}{l}\text { TS } \\
\text { IA } \\
\text { IA }\end{array}$ & $\begin{array}{l}53.85 \\
28.37 \\
44.23\end{array}$ \\
\hline $\begin{array}{l}\text { Formicinae } \\
\text { Anoplolepis longipes (Jerdon) } \\
\text { Plagiolepis alluaudi Forel } \\
\text { Paratrechina longicornis (Latreille) } \\
\text { Paratrechina bourbonica (Forel) } \\
\text { Paratrechina vaga (Forel) }\end{array}$ & $\begin{array}{l}\text { BHM } \\
\text { BHM } \\
\text { BHM } \\
\text { BHM } \\
\text { BHM }\end{array}$ & $\begin{array}{l}\text { TS } \\
\text { TS } \\
\text { TS } \\
\text { TS } \\
\text { TS }\end{array}$ & $\begin{array}{r}37.98 \\
6.25 \\
18.75 \\
51.92 \\
87.02\end{array}$ \\
\hline
\end{tabular}

${ }^{1}$ Island distribution: B, Bora Bora; H, Huahine; M, Moorea.

${ }^{2}$ Origin: TS, tramp species; IA, Indo-Australian (based on Wilson and Tayor 1967a).

${ }^{3}$ Frequency of occurrence refers to the percentage of sites at which a species was found, over all three islands combined. 